DOI https://doi.org/10.30525/978-9934-26-000-1-15

\title{
ВПЛИВ ЯК ПРІОРИТЕТНА ДОМІНАНТА МОВИ ЗМІ
}

\author{
Лакомська I. B. \\ кандидат філологічних наук, \\ дочент кафедри журналістики, реклами та медіакомунікацій \\ Одеський національний університет імені I. І. Мечникова \\ м. Одеса, Украӥна
}

Одна 3 основних функцій медіаповідомлення - це активний вплив на читача чи слухача, зацікавлення суспільно й політично важливою інформацією. Масова комунікація насамперед виконує суспільну функцію соціального регулювання, тому вчені активно наголошують на необхідності пояснення медійного впливу та зазначають, що «нині функціонування ЗМІ спрямоване не лише на пізнання й відображення дійсності, але й на іiі перетворення шляхом впливу на свідомість та підсвідомість адресата» [1, с. 3], що визначає загальну специфіку медіапростору.

Український дослідник Д. Деркач у даному аспекті зауважує, що масові комунікації стають необхідним компонентом суспільного життя, джерелом постійної інформації, що визначає формування переконань, світоглядних та ціннісних орієнтирів людини, а відтак - i функціонування мовної суспільної свідомості. Це виявляється крізь призму впливу на емоції, почуття переживання, думки реципієнта і дає змогу дослідникам розглядати таку проблематику в контексті соціальнопсихологічної інтерпретації природи масової комунікації [5, с. 49]. В цьому ж аспекті М. Володіна зауважує, що окреслюючи специфіку 3MI, у першу чергу треба звертати увагу на «питання впливу мови на людину, спосіб ії мислення, поведінку» [14]. Таким чином, $з$ наведеного випливає, що питання впливу займає надважливу ланку у вивченні функціонування засобів масової інформації та сприйняттєвих особливостей реципієнта.

Об 'єктом нашого студіювання є тексти засобів масової інформації, предметом - визначення видів мовленнєвого впливу, що використовується в межах медіапростору.

Мета дослідження - з'ясування впливового інструментарію 3МІ. Для досягнення мети поставлено такі основні завдання: ідентифікувати та проаналізувати основні види мовленнєвого впливу й визначити їхні спільні та відмінні риси.

Оглядаючи новітні наукові розробки, зазначимо, що єдиної класифікації різновидів упливу досі не існує, що зумовлює наявність різноманітних поглядів на його складники. В сучасних дослідженнях поня- 
ття сугестія, навіювання, переконування та маніпулювання часто використовуються як синонімічні поняття, що, на думку вчених (Т. Ковалевської, Н. Кутузи, О. Олексюк), є некоректним та унеможливлює термінологічну виваженість та кваліфікацію впливу. Звертаючись до визначення мовленнєвого впливу, вчені послуговуються низкою його дефінітивних характеристик, де найчастотнішими виступають поняття сугестія, або навіювання. Сугестія витлумачується як сукупність різноманітних засобів власне лінгвального й екстралінгвального (невербального) впливу, скерованого на емоційну сферу особистості з метою формування запрограмованого емоційного стану чи спонукання до певних запрограмованих дій [8, с. 51]. В. Бехтерев співвідносить сугестію 3 активацією чи штучним прищепленням сугерентові (об’єкту впливу) зовнішньо виявлюваного чи внутрішньо активованого роздратування, тобто штучного корегування усталеного для цієї особистості перебігу психічних процесів [3, с. 336].

Отже, сугестію визначають як результат некритичного сприйняття інформації й навіть зараховують до розряду сакрального, містичного [13, с. 21], розглядаючи в зазначеному аспекті слово як основний механізм здійснення сугестії [9, с. 137]. Оскільки ж головною ознакою засобів масової інформації вчені визнають їхню впливову домінанту (Т. Ковалевська, Н. Кондратенко, Н. Кутуза, О. Олексюк, В.Різун,), то лінгвістичний складник у структурі 3МІ набуває подвійної сугестивності, враховуючи наскрізну впливову природу мови (Р. Барт, Ф. Бацевич, О. Леонтьєв, Б. Поршнев, І. Черепанова).

В межах нейролінгвістичного програмування виокремлюють три етапи здійснення сугестії - рапорт, приєднання і ведення. Рапорт - це залучення уваги сугерента, та первинна інформація, яка дає змогу почати спілкування i створює у партнера намір його продовжити. Приєднання позначає «налаштування» до свідомості людини, завоювання його довіри (відповідність темпу мовлення, частоті дихання сугерента, віддзеркалювання його поз і жестів), «активне слухання», або «резонування», що програмує питання, питання на підтвердження тощо [2, с. 18-19]. Під час ведення (власне мовленнєвої дії сугестора) береться до уваги система регуляції сугерента - кінестична, візуальна, аудіальна, що викликає непомітну зміну стану і полегшує досягнення ефекту [2, с. 22].

Дефінуючи поняття навіювання, вчені характеризують його як уплив на психічний стан особистості, що виникає внаслідок зниження критичності у процесі сприйняття інформаційних блоків, відсутності логічного аналізу й об'єктивної оцінки сприйнятого, а також зв'язків із минулим досвідом сугерента, які унеможливлюють раціональне оброблення таких повідомлень [7, с. 43].Так, Т. Чмут та Г. Чайка зазначають, що навіювання може бути навмисним і ненавмисним. При навмисному навіюванні психологічний вплив є цілеспрямованим і свідомо організо- 
ваним, коли сугестор знає, кому і що він хоче навіяти і відповідно до цього добирає прийоми впливу. Бажано, щоб сугестор був людиною авторитетною, тоді йому довірятимуть [12]. При ненавмисному навіюванні «сугестор не ставить перед собою спеціальної мети, проте своїми словами та діями навіює іншому саме той стан, який би спонукав того до відповідної дії» [12]. Отже, поняття сугестія і навіювання, практично збігаються у своїх загальних стратегіях, тому маємо всі підстави для їхньго ототожнення.

Доволі часто дослідники послуговуються й терміном переконування який, проте, має істотні розбіжності з попередніми поняттями. Так, Т. Ковалевська зазначає про «... недоцільність ототожнювання понять переконування та вплив, оскільки їхні механізми «вмикають» різні процеси нейрофізіологічної інформаційної обробки (відповідно ліво та правопівкульна активація) і спираються на різні комунікативні настанови (відповідно інтеракційна емпатія, кооперативне спілкування та - імплікована експансія адресантних програм), що обгрунтовує різновекторну ідентифікацію цих процесів, де останній і є характерним для аналізованих контекстів» [6, с. 117]. Основу переконувань складає відбір, логічне впорядкування фактів і висновків згідно єдиного функційного завдання, логічний доказ, можливо, вкупі з емоційним тиском, покликані забезпечити свідоме ухвалення реципієнтом системи оцінок і думок адресанта [4, с. 192]. Отже, переконування є дією, спрямованою на свідомість особистості через звернення до іï власне критичної думки.

Досить часто у працях, де розглядається комунікативний вплив, дослідники користуються терміном маніпулювання. Це поняття сьогодні набуло негативного значення, що вживається в контексті впливу на індивідуальну чи суспільну свідомість. Так, І. Стернін характеризує маніпулювання як «вплив на людину з метою спонукати іiі повідомити інформацію, здійснити вчинок, змінити свою поведінку тощо несвідомо або всупереч іï власній позиції, наміру» [10, с. 56]. Відомий учений Г. Франке вважає, що маніпулювання тісно пов'язане 3 феноменом комунікативного впливу і співвідносне з навмисно негативним корегуванням психоструктури особистості [11]. Такий же підхід підтримано і в роботах Т. Ковалевської, Н. Кутузи, Р. Лакофф, Й. Стерніна, І. Черепанової та інших дослідників комунікативного впливу, де увиразнюється актуальність вивчення маніпулятивних ефектів комунікації, що визначається не лише загальною науковою вагою цієї проблеми, а й змогою віднайдення захисних механізмів щодо руйнівного впливу патогенних текстів, які, на думку дослідників $є$ характерною ознакою сучасного комунікативного простору.

Отже, аналіз актуальних різновидів упливу уможливив з'ясування їхньої чіткої дефініції, що дає змогу деталізувати та конкретизувати їх у текстах 3МІ. Перспективою подальших досліджень може стати аналіз 
мовних одиниць в аспекті різновидів упливу на матеріалі рекламних повідомлень.

\section{Література:}

1. Бадрак В. В. Фактори ефективності і впливу друкованих ЗМІ (преси) на електорат : автореф. дис. ... канд. філол. наук : 10.01.08. Київ, 2000. 21 с.

2. Бендлер Р., Гриндер Дж. Формирование транса. Канск: Власть Советов, 1993. $346 \mathrm{c.}$

3. Бехтерев В. М. Объективная психология. Москва : Наука, $1991.480 \mathrm{c}$.

4. Головин С. Ю. Словарь психолога-практика. Минск : Харвест, 2003. $976 \mathrm{c}$.

5. Дергач Д. В. Стилістика онімів в українських мас-медіа: монографія. Київ: Київський національний університет, 2010. 270 с.

6. Ковалевська Т. Ю. Функціональні домінанти актуальних медіатекстів: переконування чи вилив? Діалог: Медіа-студії : зб. наук. пр. Одеса , 2006. Вип. 4. С. 110-119.

7. Краткий психологический словарь / [сост. Л. А. Карпенко, под общ. ред. А. В. Петровского, М. Г. Ярошевского]. Москва : Политиздат, $1985.431 \mathrm{c}$.

8. Психологический словарь / [под ред. В. В. Давыдова, А. В. Запорожца, Б. Ф. Ломова и др.]. Москва : Педагогика, 1983. 448 с.

9. Поршнев Б. Ф. О начале человеческой истории. Проблемы палеопсихологии. Москва : Мысль, 1974. 487 с.

10. Стернин И. А Основы речевого воздействия. Изд. 2-е, испр. Воронеж : Истоки, 2012.178 с.

11. Франке Г. Манипулируемый человек. Москва : Политиздат, 1983. $190 \mathrm{c}$.

12. Чайка Г.Л., Чмут Т. К. Етика ділового спілкування : навч. посіб. 4-те вид., стер. Київ : Вікар, 2004. 223 с.

13. Черепанова И. Заговор народа. Москва : КСП+, 2002. 464 с.

14. Язык средств массовой информации: [учеб. пособие ] / под ред. М. Н. Володиной. Москва : Акад. Проект; Альма Матер, 2008. 760 с. 